\title{
THE EFFECTS OF GRAIN SIZE AND BOTTOM SLOPE ON SAND TRANSPORT IN THE COASTAL ZONE
}

\author{
L.C. van Rijn ${ }^{1}$ and S. Boer ${ }^{2}$
}

\begin{abstract}
This paper presents the effects of grain size and bottom slope on the longshore sand transport in the coastal zone (surf zone). Field data sets of sand transport in rivers, estuaries and coastal seas have been analysed to determine the effect of grain size. Three bulk-type formulae of longshore transport have been used to compute the longshore transport for a range of offshore wave conditions. Finally, a detailed cross-shore profile model (UNIBEST-TC of Delft Hydraulics) has been used to determine these effects for a new land reclamation site near the Port of Rotterdam, The Netherlands.
\end{abstract}

\section{Introduction}

The authorities of the Port of Rotterdam are planning a large-scale land reclamation (MV 2) as an extension of the present port area (MV 1). This land reclamation has been designed as a large-scale body of sand dredged from offshore locations (beyond the $-20 \mathrm{~m}$ depth contour). Figure 1 shows the new land reclamation. The southern and northern parts of the land reclamation will be defended by hard structures, but the most western part will be made of sandy bed material (sandy beach and shoreface). Two types of sand are available at the offshore source areas: $160 \mu \mathrm{m}$ or $280 \mu \mathrm{m}$ sand. To evaluate the annual erosion losses at the reclamation site related to both alternatives, a desk study was done into the effects of grain size and bed slope on sand transport in the coastal zone. Sand transport of fine material in the range of 100 to $500 \mu \mathrm{m}$ in non-steady tidal and coastal flows is strongly affected by grain size, particularly when suspended load transport is dominant. It is well known that the suspended load transport increases with decreasing grain size, as the finer particles are more easily eroded and suspended due their smaller settling velocities. However, the grain size also has a clear effect on the bottom slope in the surf zone and shoreface zone. Generally, the beach slope decreases with decreasing grain size. Beaches of finer sediments have smaller slopes (more gentle slopes) resulting in more gradual wave breaking and hence in a reduction of the longshore transport values. This latter effect is opposite to the grain size effect on sand transport. So, a smaller grain size in the coastal zone results in an increase of the sand transport rate, but it also results in a smaller beach slope and hence a decrease of the transport rate. These processes are of prime importance for the design and lifetime of sandy land reclamation and beach nourishment projects.

\footnotetext{
${ }^{1}$ Delft Hydraulics, Delft, P.O. Box 177, 2600 MH Delft, The Netherlands, leo.vanrijn@wldelft.nl

${ }^{2}$ Project Organisation, Maasvlakte 2, Rotterdam, The Netherlands
} 
The present study of the effects of grain size on sand transport in the coastal zone is based on the following approach:

- $\quad$ analysis of field data sets;

- sensitivity computations using various sand transport models in coastal flows (horizontal bottom and sloping bottoms).

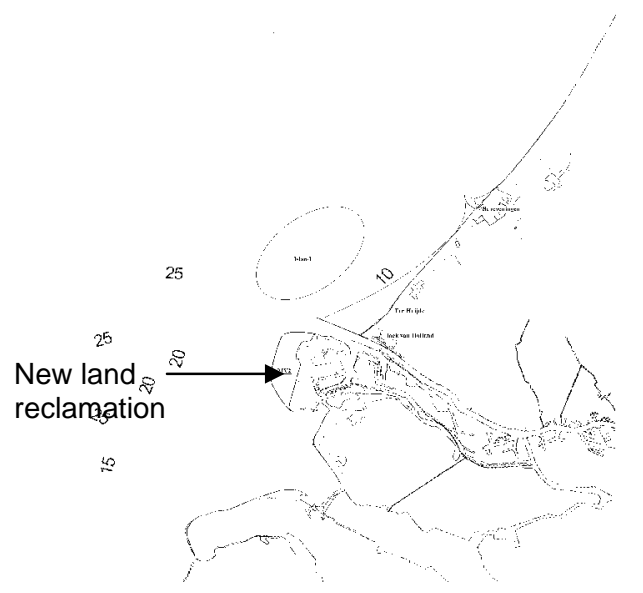

Figure 1. New land reclamation near Port of Rotterdam

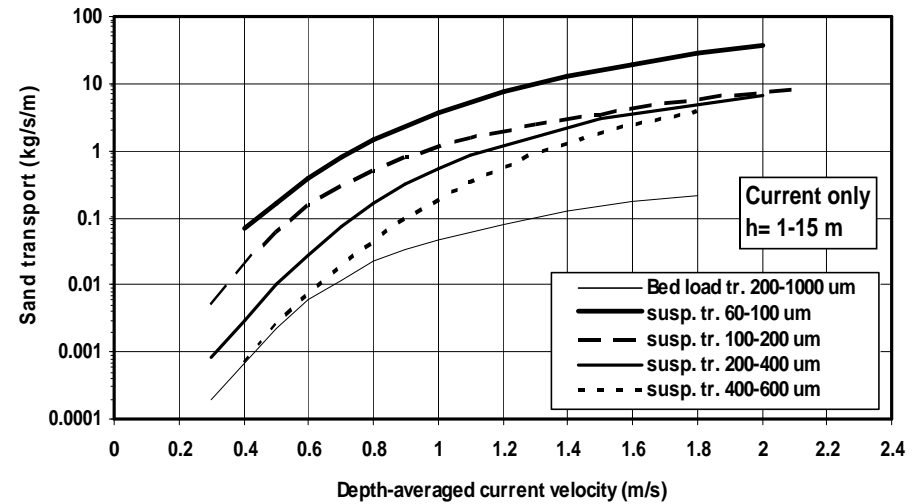

Figure 2. Trend lines of measured transport rates in rivers and estuaries 


\section{Analysis of field data}

Various reliable data sets on sand transport in (quasi) steady flow conditions (rivers and estuaries) are available in the literature (Van Rijn, 2007). Figure 2 shows the trend lines (data points are not shown) of bed load and suspended load transport as a function of the depth-averaged flow velocity. The bed load transport $\left(\mathrm{q}_{\mathrm{b}}\right.$ in $\left.\mathrm{kg} / \mathrm{s} / \mathrm{m}\right)$ can be represented by the empirical expression: $\mathrm{q}_{\mathrm{b}}=0.08\left(\mathrm{u}-\mathrm{u}_{\mathrm{cr}}\right)^{2.5}$ with $\mathrm{u}=$ depth-averaged flow velocity $(\mathrm{m} / \mathrm{s}), \mathrm{u}_{\mathrm{cr}}=$ critical depthaveraged flow velocity $=0.25 \mathrm{~m} / \mathrm{s}$. The data (grain sizes in range of 200 to 1000 $\mu \mathrm{m})$ can be represented by one single curve indicating that the bed load transport is not much affected by grain size. Figure 2 also shows the measured suspended load transport for four size classes: 60 to $100 \mu \mathrm{m}, 100$ to $200 \mu \mathrm{m}$, 200 to $400 \mu \mathrm{m}$ and 400 to $600 \mu \mathrm{m}$, indicating that the suspended load transport is strongly dependent on grain size and velocity. The effect of water depth is relatively small. The suspended load transport $\left(\mathrm{q}_{\mathrm{s}}\right.$ in $\left.\mathrm{kg} / \mathrm{s} / \mathrm{m}\right)$ can be reasonably well represented by: $\mathrm{q}_{\mathrm{s}}=\left(\mathrm{d}_{\mathrm{ref}} / \mathrm{d}_{50}\right)^{2}\left(\mathrm{u}-\mathrm{u}_{\mathrm{cr}}\right)^{3}$ with: $\mathrm{d}_{50}=$ median grain size diameter $(\mathrm{m}), \mathrm{d}_{\mathrm{ref}}=$ reference grain size diameter $=0.0003 \mathrm{~m}, \mathrm{u}=$ depth-averaged flow velocity $(\mathrm{m} / \mathrm{s}), \mathrm{u}_{\mathrm{cr}}=$ critical depth-averaged flow velocity $=0.25(\mathrm{~m} / \mathrm{s})$. Field data sets of sand transport in coastal field conditions are rather scarce. Figure 3 shows several sets of measured longshore transport rates in the surf zone of various beaches of the USA (Van Rijn, 2001, 2002). The grain sizes are in the range of 150 to $420 \mu \mathrm{m}$. A clear effect of the grain size on the longshore transport rate cannnot be detected.

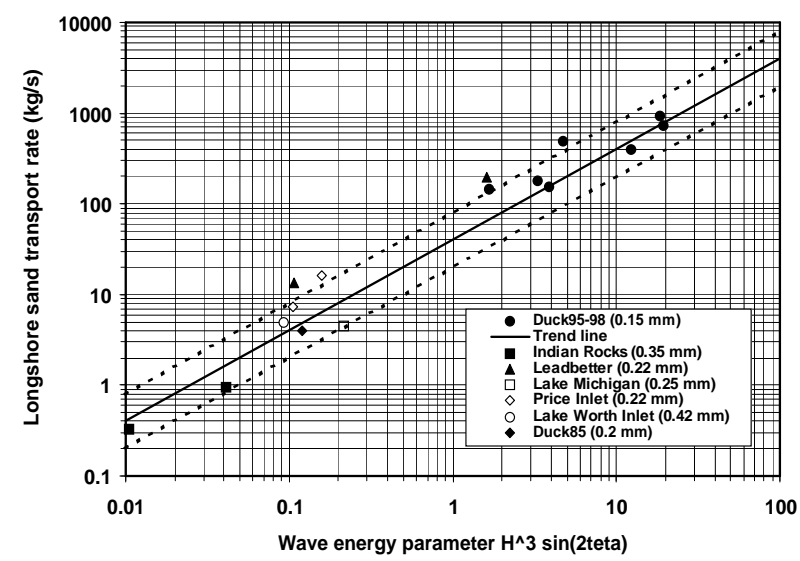

Figure 3. Measured longshore transport rates in coastal zone 


\section{Analysis of bulk-type longshore transport models}

Three bulk-type longshore sand transport formulae have been used to study the effects of grain size and bottom slope on the transport rate. Bulk-type longshore transport models are models to compute the total sediment transport in the surf zone along the coast based on the hydrodynamic conditions (wave height and period, current velocity including tide effect, angle of wave incidence) and sediment conditions at the predefined breaker line. The position of the breaker line and the hydrodynamic conditions are generally derived from the offshore conditions using refraction theory.

Three bulk longshore transport formulae used herein are (see also Van Rijn, 2001, 2002): CERC 1984, KAMPHUIS 1991 and VAN RIJN 2002.

\section{CERC formula}

The CERC-formula developed by the US-Corps of Engineers relates the immersed weight (I) of the longshore sediment transport rate to the longshore wave energy flux (Shore Protection Manual, 1984):

$\mathrm{I}=\mathrm{KE} \mathrm{c}_{\mathrm{g}, \mathrm{br}} \sin \theta_{\mathrm{br}} \cos \theta_{\mathrm{br}}$

in which:

I = longshore transport rate (immersed weight),

$\mathrm{E} \quad=1 / 8 \rho_{\mathrm{w}} \mathrm{g}\left(\mathrm{H}_{\mathrm{rms}, \mathrm{br}}\right)^{2}=$ wave energy at breaker line,

$\mathrm{H}_{\mathrm{rms}, \mathrm{br}}=$ rms wave height at breaker line,

$\mathrm{c}_{\mathrm{g}, \mathrm{br}}=\mathrm{n}_{\mathrm{br}} \mathrm{c}_{\mathrm{br}}=$ wave group celerity at breaker line,

$\theta_{\mathrm{br}}=$ wave angle at breaker line (between wave crest line and coastline; or between wave propagation direction and shore normal direction),

$\mathrm{K} \quad=\operatorname{coefficient}(=0.77)$.

Using the significant wave height $\left(\mathrm{H}_{\mathrm{s}}=\sqrt{2} \mathrm{H}_{\mathrm{rms}}\right), \rho_{\mathrm{w}}=1030 \mathrm{~kg} / \mathrm{m}^{3}, \mathrm{~K}=0.77$ and $\mathrm{p}=0.41$, it follows that:

$\mathrm{Q}_{\mathrm{t}, \mathrm{vol}}=0.023\left(\mathrm{H}_{\mathrm{s}, \mathrm{br}}\right)^{2} \mathrm{n}_{\mathrm{br}} \mathrm{c}_{\mathrm{br}} \sin \left(2 \theta_{\mathrm{br}}\right)$

in which:

$\mathrm{Q}_{\mathrm{t}, \mathrm{vol}}=\mathrm{I} /\left((1-\mathrm{p})\left(\rho_{\mathrm{s}}-\rho_{\mathrm{w}}\right) \mathrm{g}\right)=$ longshore sediment transport by volume $\left(\mathrm{m}^{3} / \mathrm{s}\right.$, including pores); the sediment transport by dry mass $\mathrm{Q}_{\mathrm{t}, \mathrm{mass}}=(1-\mathrm{p}) \rho_{\mathrm{s}} \mathrm{Q}_{\mathrm{t}, \mathrm{vol}}$,

$\mathrm{H}_{\mathrm{s}, \mathrm{br}}=$ significant wave height at the breaker line $(\mathrm{m})$, 
$\mathrm{c}_{\mathrm{br}}=$ phase velocity of the waves at the breaker line $\cong\left(\mathrm{g} \mathrm{h}_{\mathrm{br}}\right)^{0.5}$,

$\mathrm{n}_{\text {br }}=$ coefficient at breaker line $\cong 1$,

$\theta_{\mathrm{br}}=$ wave angle at the breaker line $\left(^{\circ}\right)$,

$\mathrm{h}_{\mathrm{br}}=$ water depth at the breaker line $(\mathrm{m})$,

$\mathrm{p}=$ porosity factor $(\cong 0.4)$,

$\rho_{\mathrm{s}}=$ sediment density $\left(\cong 2650 \mathrm{~kg} / \mathrm{m}^{3}\right)$.

Applying $\mathrm{n}_{\mathrm{br}} \cong 1, \mathrm{c}_{\mathrm{br}} \cong\left(\mathrm{g} \mathrm{h}_{\mathrm{br}}\right)^{0.5}$, and $\gamma_{\mathrm{br}}=\mathrm{H}_{\mathrm{br}} / \mathrm{h}_{\mathrm{br}}$, it follows that:

$\mathrm{Q}_{\mathrm{t}, \mathrm{vol}}=0.023 \mathrm{~g}^{0.5}\left(\gamma_{\mathrm{br}}\right)^{-0.5}\left(\mathrm{H}_{\mathrm{s}, \mathrm{br}}\right)^{2.5} \sin \left(2 \theta_{\mathrm{br}}\right)$

$\mathrm{Q}_{\mathrm{t}, \text { mass }}=0.023(1-\mathrm{p}) \rho_{\mathrm{s}} \mathrm{g}^{0.5}\left(\gamma_{\mathrm{br}}\right)^{-0.5}\left(\mathrm{H}_{\mathrm{s}, \mathrm{br}}\right)^{2.5} \sin \left(2 \theta_{\mathrm{br}}\right)$

Using $\mathrm{p}=0.4, \rho_{\mathrm{s}}=2650 \mathrm{~kg} / \mathrm{m}^{3}$ and $\gamma_{\mathrm{br}}=0.8$, this yields:

$\mathrm{Q}_{\mathrm{t}, \mathrm{mass}}=128\left(\mathrm{H}_{\mathrm{s}, \mathrm{br}}\right)^{2.5} \sin \left(2 \theta_{\mathrm{br}}\right)$

The CERC formula is a rather crude formula, not showing any influence of the particle diameter and the beach slope inside the surf zone. Therefore, the CERCformula is only valid for a narrow range of conditions as represented by the calibration data. According to Komar (1988), Dean (1988, 2002), Del Valle et al. (1993) and King (2005), the K-coefficient is a function of particle size (based on data with $\mathrm{d}_{50}$-values in the range of $0.15 \mathrm{~mm}$ to $1.5 \mathrm{~mm}$ ). Based on their results, the K-coefficient can be represented by: $\mathrm{K}=1.5 \exp \left(-2.5 \mathrm{~d}_{50}\right)$ with $\mathrm{d}_{50}$ in $\mathrm{mm}$.

The CERC-formula cannot be applied when tidal current velocities are significant.

\section{KAMPHUIS 1991}

Based on dimensional analysis and calibration using laboratory and field data (with grain sizes in the range of $d_{50}=200$ to $600 \mu \mathrm{m}$ and surf zone slopes in the range of $\tan \beta=0.015$ to 0.15 ), the longshore transport as immersed mass (in $\mathrm{kg} / \mathrm{s}$ ) is given by:

$\mathrm{Q}_{\mathrm{t}, \mathrm{m}}=2.33\left(\mathrm{~T}_{\mathrm{p}}\right)^{1.5}(\tan \beta)^{0.75}\left(\mathrm{~d}_{50}\right)^{-0.25}\left(\mathrm{H}_{\mathrm{s}, \mathrm{br}}\right)^{2}\left[\sin \left(2 \theta_{\mathrm{br}}\right]^{0.6}\right.$

$\mathrm{Q}_{\mathrm{t}, \mathrm{im}}=$ longshore sediment (immersed mass) transport $(\mathrm{kg} / \mathrm{s})$; the dry mass is related to the immersed mass by $\mathrm{Q}_{\mathrm{t}, \text { mass }}=\rho_{\mathrm{s}} /\left(\rho_{\mathrm{s}}-\rho_{\mathrm{w}}\right) \mathrm{Q}_{\mathrm{t} \text {,immersed mass; the }}$ conversion factor is about 1.64 ,

$\mathrm{H}_{\mathrm{s}, \mathrm{br}}=$ significant wave height at breaker line (m),

$\theta_{\mathrm{br}} \quad=$ wave angle at breaker line $\left(^{\circ}\right)$,

$\mathrm{d}_{50}=$ median particle size in surfzone $(\mathrm{m})$, 
$\tan \beta=$ beach slope defined as the ratio of the water depth at the breaker line and the distance from the still water beach line to the breaker line,

$\mathrm{T}_{\mathrm{p}} \quad=$ peak wave period.

The value 2.33 is a dimensional coefficient related to the SI system assuming salt water $\left(1030 \mathrm{~kg} / \mathrm{m}^{3}\right)$.

VAN RIJN (2001, 2002)

A simple bulk longshore transport formula was developed based on parameterization of computed transport rates of the detailed CROSMOR-model and measured transport rates in the surf zone of various beaches.

The measured longshore transport rates used in this study are shown in Figure 3 as function of the parameter $\mathrm{W}=\left(\mathrm{H}_{\mathrm{s}, \mathrm{br}}\right)^{3} \sin \left(2 \theta_{\mathrm{br}}\right)$. The empirical trendline is:

$\mathrm{Q}_{\mathrm{t}, \text { mass }}=40\left(\mathrm{H}_{\mathrm{s}, \mathrm{br}}\right)^{3} \sin \left(2 \theta_{\mathrm{br}}\right)$

with:

$\mathrm{Q}_{\mathrm{t}, \text { mass }}=$ longshore sand transport (in $\mathrm{kg} / \mathrm{s}$; dry mass),

$\mathrm{H}_{\mathrm{s}, \mathrm{br}}=$ significant wave height at breakerline (in $\mathrm{m}$ ),

$\theta_{\mathrm{br}}=$ angle of wave incidence at breakerline to coast normal (in degrees).

Most of the data are within a factor of 2 of the trendline. The trendline is valid for sand with $\mathrm{d}_{50}$ between 150 and $500 \mu \mathrm{m}$ and bed slopes between 0.02 and 0.1 . The data set is too small to detect any effect of grain size and/or bed slope.

Using an approach similar to that of Bagnold (1963) and Komar (1979), the empirical trendline can also be expressed as:

$\mathrm{Q}_{\mathrm{t}, \text { mass }}=\mathrm{K}_{1}\left(\mathrm{H}_{\mathrm{s}, \mathrm{br}}\right)^{2.5} \mathrm{~V}_{\mathrm{wave}, \mathrm{L}}$

$\mathrm{V}_{\text {wave }, \mathrm{L}}=\mathrm{K}_{2}\left(\mathrm{gH}_{\mathrm{s}, \mathrm{br}}\right)^{0.5} \sin \left(2 \theta_{\mathrm{br}}\right)$

with:

$\mathrm{V}_{\text {wave, } \mathrm{L}} \quad=$ longshore velocity in mid of surf zone due to breaking waves, $\mathrm{K}_{1} \mathrm{~K}_{2} \mathrm{~g}^{0.5}=40$.

Using Equation (8), the longshore transport rate is described as a combination of a wave-related stirring parameter and a wave-driven longshore current velocity $\left(\mathrm{V}_{\text {wave,L}}\right)$ in the middle of the surf zone. This approach can be used to include the tide-driven longshore velocity. Computed transport rates produced by the 
CROSMOR-model for different grain sizes and bed slopes have been used to determine these effects explicitly.

The results have been used to determine a simplified formula for the longshore sand transport (incl. all effects), which reads as:

$\mathrm{Q}_{\mathrm{t} \text {,mass }}=42 \mathrm{~K}_{\text {swell }} \mathrm{K}_{\text {grain }} \mathrm{K}_{\text {slope }}\left(\mathrm{H}_{\mathrm{s}, \mathrm{br}}\right)^{2.5} \mathrm{~V}_{\text {eff } \mathrm{L}}$

with:

$\mathrm{Q}_{\mathrm{t}, \text { mass }} \quad=$ longshore sand transport (in $\mathrm{kg} / \mathrm{s}$, dry mass);

$\mathrm{H}_{\mathrm{s}, \mathrm{br}} \quad=$ significant wave height at breakerline (m);

$\mathrm{V}_{\text {eff, } \mathrm{L}} \quad=\left[\left(\mathrm{V}_{\text {wave }, \mathrm{L}}\right)^{2}+\left(\mathrm{V}_{\text {tide, } \mathrm{L}}\right)^{2}\right]^{0.5}=$ effective longshore velocity at mid surf zone $(\mathrm{m} / \mathrm{s})$ for tidal velocity and wave-induced velocity in the same direction (minus sign for opposing conditions);

$\mathrm{V}_{\text {wave } \mathrm{L}} \quad=0.3\left(\mathrm{gH}_{\mathrm{s}, \mathrm{br}}\right)^{0.5} \sin \left(2 \theta_{\mathrm{br}}\right)=$ wave-induced longshore velocity in mid surf zone (incl. wind effect);

$\mathrm{V}_{\text {tide } \mathrm{L}} \quad=$ longshore velocity in mid surf zone due to tidal forcings $(=0$ for non-tidal cases; $0.1 \mathrm{~m} / \mathrm{s}$ for micro-tidal, $0.3 \mathrm{~m} / \mathrm{s}$ for meso-tidal and $0.5 \mathrm{~m} / \mathrm{s}$ for macro-tidal cases);

$\theta_{\mathrm{br}} \quad=$ wave incidence angle at the breakerline (to shore normal; in degrees);

$\mathrm{K}_{\text {swell }} \quad=\mathrm{T}_{\text {swell }} / \mathrm{T}_{\text {ref }}=$ swell correction factor for swell waves $<2 \mathrm{~m}$, with $\mathrm{T}_{\text {ref }}=$ reference wave period $=6 \mathrm{~s} ; \mathrm{K}_{\text {swell }}=1$ for wind waves;

$\mathrm{K}_{\text {grain }}=\left(\mathrm{d}_{50, \text { re }} / \mathrm{d}_{50}\right)=$ particle size correction factor with $\mathrm{d}_{50}$ in $\mathrm{mm}$, $\left(\mathrm{d}_{50, \text { ref }}=0.2 \mathrm{~mm}\right)$, with $\mathrm{K}_{\text {grain,min }}=0.1$ for $\mathrm{d}_{50}>2 \mathrm{~mm}$;

$\mathrm{K}_{\text {slope }} \quad=\left(\tan \beta / \tan \beta_{\text {ref }}\right)^{0.5}=$ bed slope correction factor;

$\mathrm{K}_{\text {slope, } \max }=1.25, \mathrm{~K}_{\text {slope, } \min }=0.75, \tan \beta=$ actual bed slope, $\tan \beta_{\text {ref }}=0.01$ (reference slope of Egmond profile); the overall profile slope is defined as the slope between the waterline and the $8 \mathrm{~m}$ depth contour; $\tan \beta=8 / \mathrm{B}$ with $\mathrm{B}=$ distance between waterline and location of $8 \mathrm{~m}$ depth contour seaward of outer breaker bar); the beach slope of the inner surf zone slope cannot be used in the slope correction factor!

For a zero tidal velocity $\left(\mathrm{V}_{\text {tide, } \mathrm{L}}=0 \mathrm{~m} / \mathrm{s}\right)$, it results in:

$\mathrm{Q}_{\mathrm{t} \text {,mass }}=40 \mathrm{~K}_{\text {swell }} \mathrm{K}_{\text {grain }} \mathrm{K}_{\text {slope }}\left(\mathrm{H}_{\mathrm{s}, \mathrm{br}}\right)^{3} \sin \left(2 \theta_{\mathrm{br}}\right)$

Assuming a straight uniform coast with parallel depth contours, the water depth at the breakerline (location where 5\% of the waves are breaking) can be estimated from: 
$\mathrm{h}_{\mathrm{br}}=\left[\left(\mathrm{H}_{\mathrm{s}, \mathrm{o}}{ }^{2} \mathrm{c}_{\mathrm{o}} \cos \theta_{\mathrm{o}}\right) /\left(\alpha \gamma^{2} \mathrm{~g}^{0.5}\right)\right]^{0.4}$

The wave incidence angle at the breakerline $\left(\theta_{\mathrm{br}}\right)$ can be determined from:

$\sin \theta_{\mathrm{br}}=\left(\mathrm{c}_{\mathrm{br}} / \mathrm{c}_{\mathrm{o}}\right) \sin \theta_{\mathrm{o}}$

with:

$\mathrm{H}_{\mathrm{s}, \mathrm{o}} \quad$ = significant wave height at deep water,

$\mathrm{c}_{\mathrm{o}}, \mathrm{c}_{\mathrm{br}}=$ wave propagation speed at deep water and at breakerline,

$\theta_{\mathrm{o}}, \theta_{\mathrm{br}}=$ wave incidence angle (to shore normal) at deep water and at breakerline,

$\gamma \quad=\mathrm{H}_{\mathrm{s}, \mathrm{br}} / \mathrm{h}_{\mathrm{br}}=$ breaking coefficient based on $5 \%$ breaking $=0.4$,

$\alpha \quad=1.8$, calibration coefficient,

$\mathrm{L}_{\mathrm{o}} \quad=(\mathrm{g} / 2 \pi) \mathrm{T}_{\mathrm{p}}^{2}=$ wave length in deep water.

Summarizing, the empirical formula of CERC is mainly valid for grain sizes between 200 and $600 \mu \mathrm{m}$ in conditions with very small tidal flows. The influences of grain size and bottom slope are not taken into account. According to Komar (1988), Dean (1988, 2002), Del Valle et al. (1993) and King (2005), the K-coefficient is roughly proportional to $1 / \mathrm{d}_{50}$. Thus, $\mathrm{Q}_{\mathrm{t}} \approx\left(\mathrm{d}_{50}\right)^{-1}$, which is in agreement with the $\mathrm{K}_{\text {grain }}$-coefficient of VAN RIJN ( see Equation 9 ).

The formula of KAMPHUIS (1991) yields: $\mathrm{Q}_{\mathrm{t}} \approx(\tan \beta)^{0.75}\left(\mathrm{~d}_{50}\right)^{-0.25}$, which means that the longshore transport decreases with increasing grain size and increases with increasing bottom slope.

The formula of VAN RIJN $(2001,2002)$ yields: $Q_{t} \approx(\tan \beta)^{0.5}\left(d_{50}\right)^{-1}$.

The three bulk-type longshore transport formulae have been applied in a sensitivity study, using the following data:

- $\quad$ two grain sizes: 285 and $160 \mu \mathrm{m}$;

- three bottom slopes in the surf zone between the water line and the breaker line: 1 to $60(\tan \beta=0.0166), 1$ to $75(\tan \beta=0.01333)$ and 1 to $90(\tan$ $\beta=0.01111)$;

- $\quad$ offshore wave angle $=20$ degrees (at depth of $20 \mathrm{~m}$ );

- $\quad$ offshore wave heights: 1.5, 3, 4.5 and $6 \mathrm{~m}$ (at depth of $20 \mathrm{~m}$ );

- $\quad$ wave periods: $5,7,9$ and $11 \mathrm{~s}$;

- tidal flow velocity $=0.5 \mathrm{~m} / \mathrm{s}$ (only in formula of Van Rijn);

- $\quad$ Breakercoefficient $=0.6$.

The results (longshore transport rates in $\mathrm{m}^{3} /$ day, incl. pores) are shown in Figures 4, 5 and 6 . It can be observed that the longshore transport of 
KAMPHUIS at a steep slope (0.0166) using coarse sand $(285 \mu \mathrm{m})$ is always larger (approx. 15\%) than that at a mild slope (0.0111) using fine sand (160 $\mu \mathrm{m})$; the bottom slope effect is largest. The longshore transport rates of VAN RIJN show precisely opposite results; the grain size effect is largest. The CERC formula shows no effect of grain size and bottom slope.

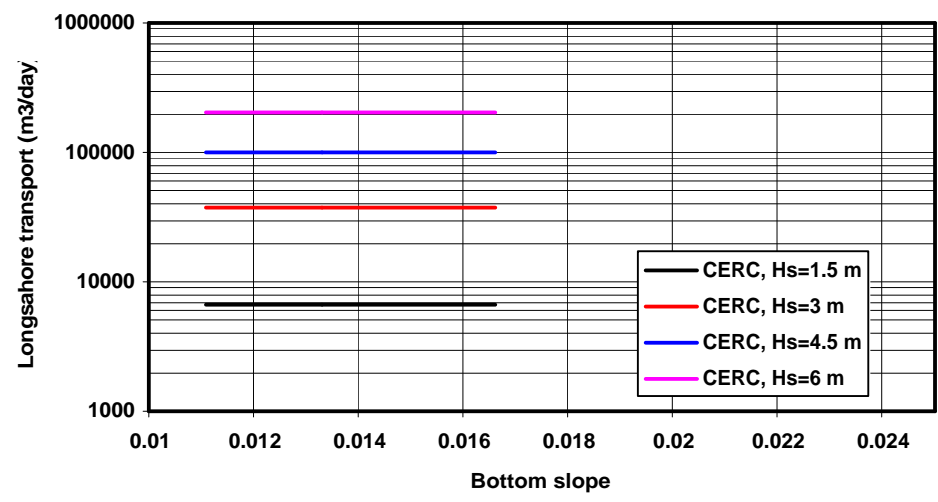

Figure 4. Longshore transport of CERC as function of grain size and bottom slope

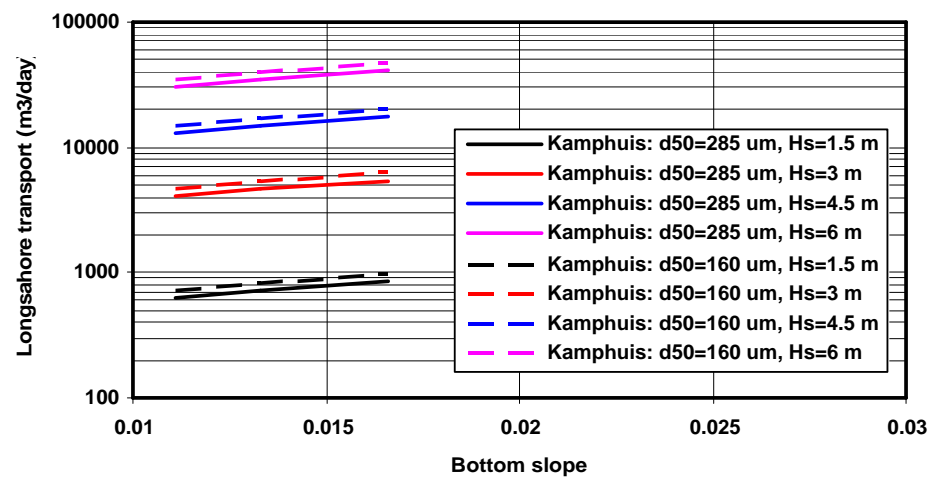

Figure 5. Longshore transport of KAMPHUIS as function of grain size and bottom slope 


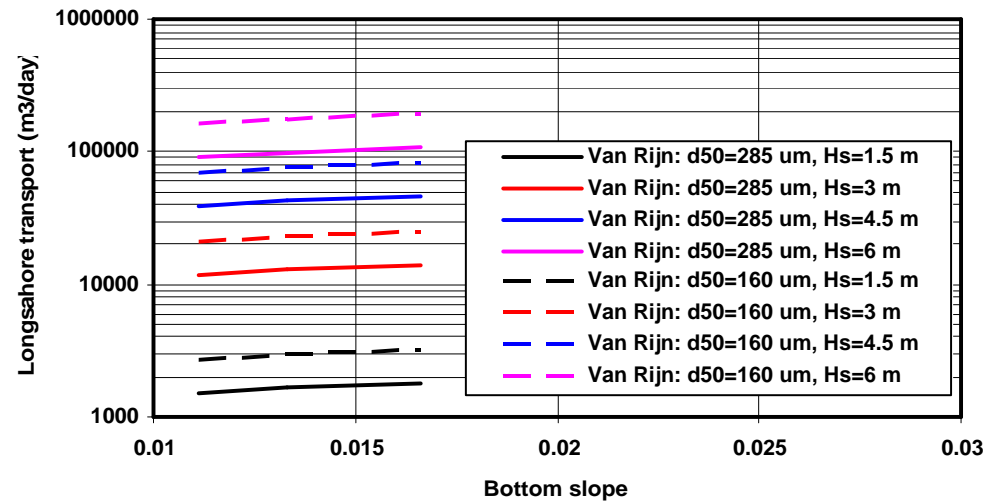

Figure 6. Longshore transport of VAN RIJN as function of grain size and bottom slope

Similar computations have been made using the cross-shore model UNIBESTTC (Delft Hydraulics) along 4 different cross-shore profiles as given in Table 1. To determine the longshore transport rate by integration, the width of the surf zone should be known. Two approaches have been used: a constant width of $1000 \mathrm{~m}$ (which is most practical for reasons of maintenance of the amount of sand in the coastal zone) and a variable width determined by the breaker criterion $\mathrm{H}_{\mathrm{s}, \mathrm{o}} / \mathrm{h}=0.6$. In the latter case the width of the surf zone varies between approximately $500 \mathrm{~m}$ (steep sloping profile) to $700 \mathrm{~m}$ (mildly sloping profile). The assumption of a surf zone with a constant width of $1000 \mathrm{~m}$ may lead to larger longshore transport rates and hence erosion losses as the surf zone is much wider than that based on a variable width (width of $500 \mathrm{~m}$ to $700 \mathrm{~m}$ ).

\begin{tabular}{|c|c|c|c|c|c|}
\hline Type of Profile & $\begin{array}{l}\text { Beach } \\
\text { zone } \\
(+3 \text { to } \\
+1 \mathrm{~m})\end{array}$ & $\begin{array}{l}\begin{array}{l}\text { Swash } \\
\text { zone } \\
(+1 \text { to } \\
-1 \mathrm{~m})\end{array} \\
-1\end{array}$ & $\begin{array}{l}\text { Surf } \\
\text { zone } \\
(-1 \text { to } \\
-5 \mathrm{~m})\end{array}$ & $\begin{array}{l}\text { Shoreface } \\
\text { (deeper } \\
\text { than }-5 \mathrm{~m} \text { ) }\end{array}$ & $\begin{array}{l}\text { Shoreface } \\
\text { (transition } \\
\text { to }-\mathbf{2 0} \mathbf{~ m} \text { ) }\end{array}$ \\
\hline Design-profile & 1 to 25 & 1 to 50 & 1 to 75 & 1 to 100 & 1 to 20 \\
\hline Steep profile & 1 to 20 & 1 to 40 & 1 to 60 & 1 to 80 & 1 to 20 \\
\hline Mild profile & 1 to 30 & 1 to 60 & 1 to 90 & 1 to 120 & 1 to 20 \\
\hline $\begin{array}{l}\text { Very steep } \\
\text { profile }\end{array}$ & 1 to 20 & 1 to 20 & 1 to 20 & 1 to 40 & $\begin{array}{l}1 \text { to } 60 \\
\text { (-10 to } \\
-20 \mathrm{~m})\end{array}$ \\
\hline
\end{tabular}

Table 1. Cross-shore bottom profiles at the land reclamation side 


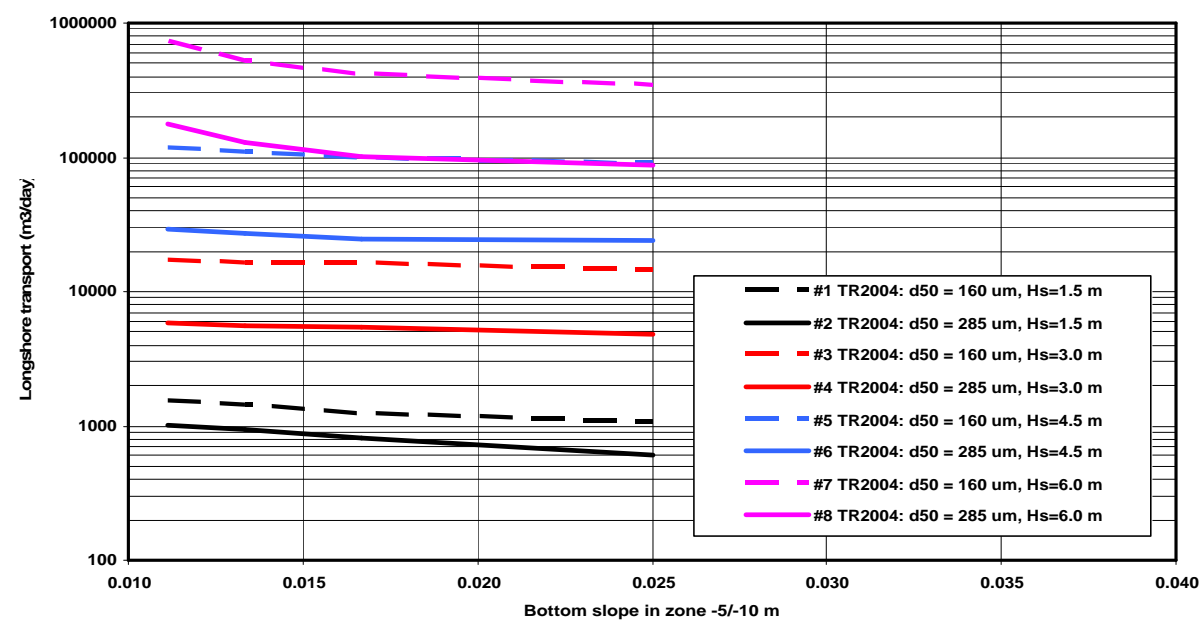

Figure 7. Longshore transport based on UNIBEST-TC model as function of bottom slope and grain size; variable width of surf zone

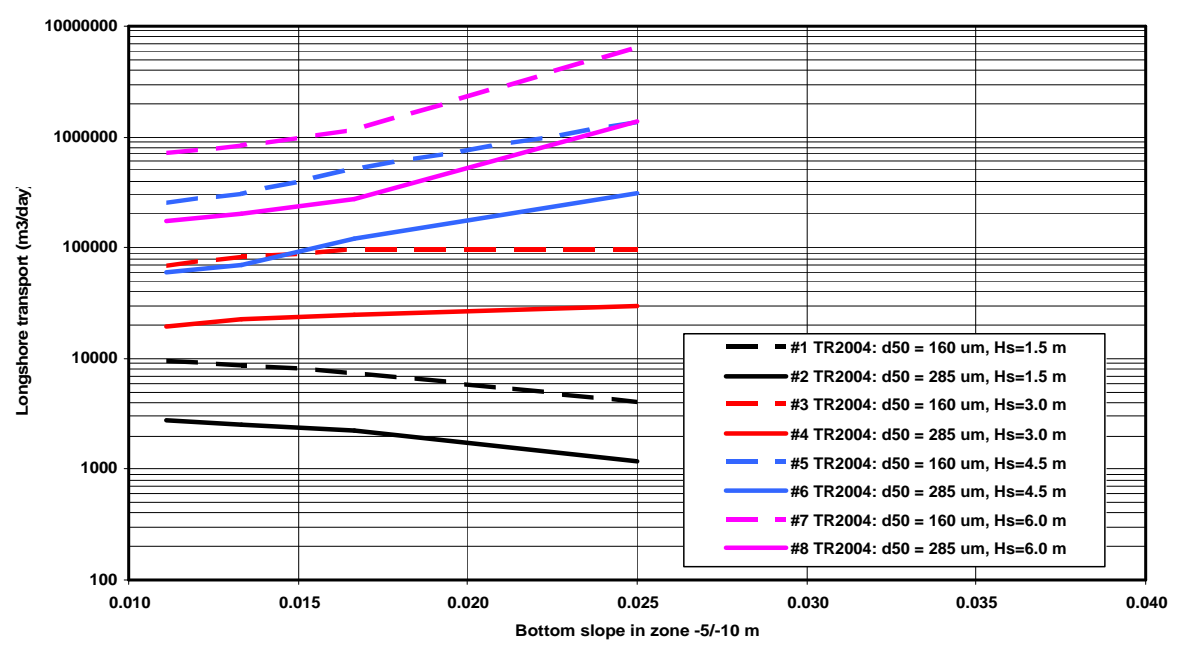

Figure 8. Longshore transport based on UNIBEST-TC model as function of bottom slope and grain size; constant width of surf zone $(=1000 \mathrm{~m})$

The results are shown in Figures 7 and 8 . In the case of low waves $\left(\mathrm{H}_{\mathrm{s}, \mathrm{o}}=1.5 \mathrm{~m}\right)$ the longshore transport rate decreases slightly for increasing bottom slope both for variable and constant width of the coastal zone. 
In the case of high waves $\left(\mathrm{H}_{\mathrm{s}, \mathrm{o}}=3\right.$ tot $\left.6 \mathrm{~m}\right)$ the longshore transport rate increases significantly for increasing bottom slope (assuming that the coastal zone has a constant width of $1000 \mathrm{~m}$ ), because the relatively large transport values in deeper water (depth of about $10 \mathrm{~m}$ ) due to tidal flow (superimposed by relatively large waves) are included.

The bottom slope effect is strongly affected by the width of the surf zone. In the case of a constant width of $1000 \mathrm{~m}$ the largest transport rates are obtained for the steepest profile, except at low waves $\left(\mathrm{H}_{\mathrm{s}, \mathrm{o}}=1.5 \mathrm{~m}\right)$. The slope effect is marginal at low waves, because the decrease of the longshore transport for decreasing surf zone width and the increase of transport for increasing bottom slope are cancelling out.

\section{Conclusions}

The following conclusions are given:

- The longshore sand transport in the case of fine sand of about $160 \mu \mathrm{m}$ is about 3 to 4 times larger than that of coarse sand of $285 \mu \mathrm{m}$ at the same beach slope.

- The longshore sand transport (including tide and wind-driven flows) in the coastal zone with a width of $1000 \mathrm{~m}$ increases by a factor of 2 to 4 when the bottom slope increases by a factor of 2 and major storms are present $\left(\mathrm{H}_{\mathrm{s}, \mathrm{o}}>\right.$ $3 \mathrm{~m})$.

- The longshore sand transport (including tide and wind-driven flows) of fine sand along a gentle profile (constant width case) is about equal to that of coarse sand along a steep profile in the case of major storms $\left(\mathrm{H}_{\mathrm{s}, \mathrm{o}}>3 \mathrm{~m}\right)$ and is about 3 to 6 times larger in the case of minor storms $\left(\mathrm{H}_{\mathrm{s}, \mathrm{o}}<3 \mathrm{~m}\right)$.

\section{REFERENCES}

Dean, R.G., 1988. Measuring longshore transport with traps. In: nearshore sediment transport edited by Richard J. Seymour, Plenum Press, New York, USA

Dean, R.G., 2002. Beach nourishment: Theory and Practice. World Scientific

Del Valle, R., Medina, R. and Losada, M.A., 1993. Dependence of coefficient $\mathrm{K}$ on grain size. Journal of Waterway, Port, Coastal and Ocean Engineering, p. 568-574 
Bagnold, R.A., 1963. Mechanics of Marine Sedimentation, in: The Sea, Vol. 3, p. 507-528, edited by M.N. Hill, Interscience, NY

Komar, P.D. ,1979. Beach slope dependence of longshore currents. Journal of Waterway, Port, Coastal and Ocean Division, ASCE, Vol. 105, WW 4

Komar, P.D., 1988. Environmental controlls on littoral sand transport. $21^{\text {st }}$ ICCE, Malaga, Spain, p. 1238-1252

Kamphuis, J.W., 1991. Alongshore sediment transport rate. Journal of Waterway, Port, Coastal and Ocean Eng., Vol. 117, p. 624-640

King, D.B., 2005. Influence of grain size on sediment transport rates with emphasis on the total longshore rate. USACE, Vicksburg, USA

Shore Protection Manual, 1984. CERC, Waterways Experiment Station, Vicksburg, USA

Van Rijn, L.C., 2001. Longshore sediment transport, Report Z3054, Delft Hydraulics, Delft, The Netherlands

Van Rijn, L.C., 2002. Longshore sand transport. $28^{\text {th }}$ ICCE, Cardiff, Wales, United Kingdom 2006

Van Rijn, L.C., 2007. A unified view of sediment transport by currents and waves, Part 2: Suspended transport. Accepted by Journal of Hydraulic Engineering, ASCE 